\title{
Edible flowers: more than a gastronomic trend
}

\author{
Elisabeth Regina Tempel Stumpf $\mathrm{f}^{1,2}$ (1) \\ ${ }^{1}$ Plant Breeding and New Crops Area-Editor, Ornamental Horticulture, Viçosa-MG, Brazil \\ ${ }^{2}$ Instituto Federal Sul Rio-Grandense, Pelotas-RS, Brazil.
}

Since ancient times, flowers and symbols blend and complement each other in a permanent harmony. Victory, love, arrivals and farewells. Flowers also indicates the harbinger of life, hope for preservation and continuity of the species. Its meanings and uses are recognized and diverse, and permeate generations all over the world. Perfumes, infusions, medicines and food make up the wide and varied spectrum of use in different cultures. The use of flowers in cooking is well known. Its beauty and nutritional properties provide different uses, from the aesthetic to the composition of the most differentiated menus.

The nutrients provided by food are essential for maintaining health, well-being and life in all its phases. Therefore, food should not only be accessible, from a physical and financial point of view, but also be healthy, safe, nutritious and varied.

However, in recent decades, there has been a marked narrowing of the supply matrix that reaches the tables, causing great and serious problems to people's health. Although there are between 250,000 and 420,000 species of higher plants, $95 \%$ of human nutrition is based on only thirty of them. $75 \%$ of this total consists of rice, corn, wheat, barley, potato, cassava and sweet potatoes (Walter et al., 2005). This food narrowing is due to the process of industrialization in the countryside, with techniques and technologies brought about by the green revolution, and by the vertiginous growth of the supply and consumption of ultra-processed foods.

The substitution of fresh or minimally processed foods with industrialized and/or ultra-processed products, observed as a feeding pattern, generated an imbalance in the supply of nutrients. Currently, however, a new generation of consumers emerges, more conscious, who adopt healthy habits, where the nutritional value of food, combined with the pleasurable experience in the use of new ingredients and flavors, assume outstanding importance. These consumers also show concern with the origin and production processes of their food, and with the social and environmental impact that their choices can generate (Filipe, 2017).

Data show that, in 2019, about $40 \%$ of Brazilian consumers already sought to reduce the impact of their consumption on the environment, stimulating a change in eating habits, such as the search for organic foods, for example (Nielsen, 2019). In the following year, another study pointed out that $90 \%$ of Brazilians would be willing to try products derived from plants, especially due to their health concerns, nutritional value and differentiated flavor (Vasconcellos, 2020).

Numerous plant species are used in gastronomy, including edible flowers, whose consumption dates back thousands of years. These were used to beautify and flavor dishes, and in the preparation of drinks, sauces, salads, breads, cheese and candies.

Over time, the use of flowers was restricted to special occasions and preparations. However, in order to meet the new consumer demand, contemporary gastronomy has been adopting the use of edible flowers, often as the main ingredient of the recipes.

Flowers of ornamental, fruit, aromatic, medicinal and vegetable species may be used, as well as non-conventional species. However, for safe insertion in human food, it is necessary to correctly identify the species that produce flowers to be consumed, verifying their properties and know the production system. In addition, it is necessary to identify the parts of the flowers that can be consumed, to check for the presence of toxic and/or allergenic compounds and, above all, to know their nutritional properties (Guiné et al., 2021).

Inflorescences of cauliflower and broccoli, as well as whole pumpkin flowers, are recognized as food. Aromatic herb flowers, such as rosemary and basil, have been used since they have a more pronounced flavor than the commonly used leaves. Pansy flowers, a well-known ornamental species, already have good acceptance and use in cooking. Often, however, only parts of the flowers of a particular species are edible. Well-known examples are artichoke bracts, marigold ligules, rose petals and saffron stigmas. Pollen, nectar and essential oils extracted from flowers of some species can also add different flavors and aromas to the palate.

There are some toxic flowers that, due to their morphological characteristics, can be easily confused with edible species. Also, others, toxic or edible, may have identical common names, depending on the region where they are grown or occur (Guiné and Correia, 2017). In this respect, the correct botanical identification is essential for safe consumption. Special care should also be given to toxic or allergenic substances that some flowers, or parts of them, may contain, making their consumption unfeasible.

*Corresponding author: elisabeth.stumpf@gmail.com 
The main argument for flower consumption is undoubtedly in their nutritional properties. Most of them have a significant quantity of proteins, carbohydrates/ fibers, vitamins (notably A, C and E), minerals (especially $\mathrm{P}, \mathrm{K}, \mathrm{Ca}$ and $\mathrm{Mg}$ ), carotenoids, flavonoids, anthocyanins, antioxidants and essential oils. The contents of these compounds vary among the species, which reveals a promising source for research.

As for the production system, it must be organic, adopted from the origin of the seeds to the harvesting and post-harvesting techniques. On the other hand, not only due to their fragility and perishability, but also to avoid contamination, the handling of flowers during storage, distribution, marketing and preparation, requires the use of strict hygiene and safety standards.
In addition to these aspects, production and distribution systems should promote social justice and protect natural resources and biodiversity.

Therefore, edible flowers present themselves as a new and vast multidisciplinary field for research. Studies on nutritional and toxicological composition; content and use of essential oils; evaluation of sensory characteristics (color, flavor and aroma); safe quantity and frequency for the consumption; production, harvesting, storage, handling and processing techniques; potential consumption of native flowers; consumer perception and acceptance; marketing for the dissemination, popularization and promotion of consumption and, of course, creation of recipes for uses in gastronomy, are just some of the possibilities.

\section{References}

FILIPE, S.B. Novos produtos para novos consumidores. In: GONÇALVES, J.C.; DELGADO, F.; GARCIA, A.R.; FILIPE, S.B. (Org). Geoaromas: a inovação na gastronomia - receitas. Castelo Branco: RVJ, 2017. 96p.

GUINÉ, R.P.F.; SANTOS, E.; CORREIA, P. Edible flowers: knowledge and consumption habits. Acta Scientific Nutritional Health, v.1, n.3, 18-22, 2017.

GUINÉ, R.P.F.; FLORENÇA, S.G.; FERRÃO, A.C., BIZJAK, M.Č.; VOMBERGAR, B.; SIMONI, N.; VIEIRA, V. Factors affecting eating habits and knowledge of edible flowers in different countries. Open Agriculture, n.6, p.67-81, 2021. https://doi.org/10.1515/opag-2020-0208.

NIELSEN. 2019. Brasileiros estão cada vez mais sustentáveis e conscientes. Available in: < https://www.nielsen.com/ br/pt/insights/article/2019/brasileiros-estao-cada-vez-mais-sustentaveis-e-conscientes/>. Accessed on: May $31^{\text {th }} 2021$.

VASCONCELLOS, C.E. 2020. Plant-based: alimentação saudável e sustentável atrai brasileiros. Available in: <https:// www.consumidormoderno.com.br/2020/10/02/plant-based-alimentacao-saudavel-e-sustentavel-atrai-brasileiros/>. Accessed on: May $31^{\text {th }} 2021$.

WALTER, B.M.T.; CAVALCANTI, T.B.; BIANCHETTI, L.B.; VALLS, J.F.M. Coleta de germoplasma vegetal: relevância e conceitos básicos. In: WALTER, B.M.T.; CAVALCANTI, T.B. (Ed.) Fundamentos para a coleta de germoplasma vegetal. Brasília: Embrapa Recursos Genéticos e Biotecnologia, 2005. p.27-55 